\title{
KONTRIBUSI USAHATANI KACANG PANJANG TERHADAP PENDAPATAN RUMAH TANGGA PETANI DI DESA WAREMBUNGAN KECAMATAN PINELENG
}

\author{
Achelien L. Paulus \\ Welson M. Wangke \\ Vicky R.B. Moniaga
}

\begin{abstract}
This study aims to measure how big the contribution of farming beans on household income of farmers in the village of the District Warembungan, Pineleng Sub-district. Collecting data started from May 2015 to July 2015. Primary data were collected through interviews based on questionnaires and secondary data is data obtained from the Village Government Warembungan and scientific papers related to the study. The data in this research is descriptive analysis and presented in tabular form. The results showed that long bean farming can contribute to the family income of farmers per year in the village of the Warembungan, Village, Pineleng subdistrict by 36.33 percent. This suggests that long bean farm income is inportant source of income for farmers who make an important contribution, because the value of long bean farm income to total family income farmers can increase their income more than 35 percent to the total household income of farmers.
\end{abstract}

Keyword: Income contribution, long bean, Warembungan-Pineleng

\begin{abstract}
ABSTRAK
Penelitian ini bertujuan untuk mengukur berapa besar kontribusi usahatani kacang panjang terhadap pendapatan rumah tangga petani di Desa Warembungan Kecamatan Pineleng. Pengumpulan data di mulai dari bulan Mei 2015-Juli 2015. Data yang dikumpulkan adalah data primer melalui kuisioner dan data sekunder yaitu data yang diperoleh dari Pemerintah Desa Warembungan serta karya tulis ilmiah yang berkaitan dengan penelitian ini. Teknik analisis dalam penelitian ini adalah analisis deskriptif dan disajikan dalam bentuk tabel. Hasil penelitian menunjukkan bahwa usahatani kacang panjang dapat memberikan kontribusi bagi pendapatan keluarga petani per tahun di Desa Warembungan Kecamatan Pineleng sebesar 36.33 persen. Hal ini menunjukkan bahwa pendapatan usahatani kacang panjang merupakan sumber mata pencaharian petani yang memberikan kontribusi penting, karena nilai pendapatan usahatani kacang panjang terhadap total pendapatan keluarga petani dapat meningkatkan pendapatan lebih dari 35 persen pada total pendapatan rumahtangga petani.
\end{abstract}

Kata Kunci: Kontribusi pendapatan, kacang panjang, Warembungan-Pineleng

\section{PENDAHULUAN}

\section{Latar Belakang}

Sektor pertanian hingga kini masih tetap menjadi tumpuan pertumbuhan ekonomi daerah Provinsi Sulawesi Utara. Pendapatan sebagian besar masyarakat di daerah masih sangat bergantung pada sektor pertanian yaitu melibatkan sekitar 50-60\% dari tenaga kerja. (Sondakh, dkk 2008 dalam Timbulus 2015). Sebagian orang meng- artikan pertanian sebagai kegiatan manusia dalam membuka la- han dan menanaminya dengan berbagai jenis tanaman, baik tanaman semusim maupun tanaman tahunan, tanaman pangan maupun non pangan (Suratiyah, 2015).

Kecamatan Pineleng telah memberikan kontribusi yang positif bagi pembangunan ekonomi di Kabupaten Minahasa dengan potensi yang dimiliki oleh Kecamatan Pineleng ini (BPS, 2014). Seperti pada Tabel 1 berikut yang menunjukkan Jumlah Penduduk Menurut Jenis Pekerjaan di Kecamatan Pineleng. 
Tabel 1. Jumlah Penduduk Menurut Jenis Pekerjaan di Kecamatan Pineleng, 2015.

\begin{tabular}{|c|c|c|c|c|c|c|}
\hline No. & Desa & $\begin{array}{c}\text { Tanaman } \\
\text { pangan }\end{array}$ & Perkebunan & Peternakan & Perikanan & $\begin{array}{l}\text { Lain- } \\
\text { lain }\end{array}$ \\
\hline 1. & Kali & 153 & 263 & 48 & 9 & 461 \\
\hline 2. & Kali Selatan & 145 & 206 & 41 & 7 & 91 \\
\hline 3. & Winangun Atas & 88 & 261 & 82 & - & 135 \\
\hline 4. & Lotta & 116 & 244 & 51 & 5 & 522 \\
\hline 5. & Pineleng & 256 & 387 & 37 & 11 & 194 \\
\hline 6. & Pineleng 1 Timur & 78 & 94 & 23 & - & 105 \\
\hline 7. & Pineleng 2 & 219 & 303 & 65 & 9 & 169 \\
\hline 8. & Pineleng 2 Indah & 45 & 16 & 7 & - & 223 \\
\hline 9. & Warembungan & 442 & 521 & 91 & 13 & 331 \\
\hline 10. & Sea & 415 & 597 & 492 & 19 & 165 \\
\hline 11. & Sea 1 & 135 & 140 & 12 & - & 277 \\
\hline 12. & Sea 2 & 77 & 89 & 18 & - & 91 \\
\hline 13. & Sea Mitra & 92 & 91 & 16 & - & 56 \\
\hline 14. & Sea Tumpengan & 132 & 136 & 21 & - & 476 \\
\hline & Jumlah & 2393 & 3248 & 1004 & 73 & 3603 \\
\hline
\end{tabular}

Sumber : Data Kantor Kecamatan Pineleng, 2015.

Pada Tabel 1 dapat dilihat pada urutan nomor 9, Desa Warembungan memiliki petani tanaman pa-ngan berjumlah 442, perkebunan 521, peternakan 91, perikanan 13 dan lain-lain (seperti : Pensiunan, Pegawai Negeri Sipil, Guru, Swasta, Tukang) (Data Kantor Hukum Tua Desa Warembungan, 2015). Desa Warembungan merupakan desa yang letaknya strategis karena, berada di dekat Kota Manado, yang bisa di jangkau oleh siapa saja. Meskipun letak dari desa ini dikatakan strategis ternyata masyarakat di desa ini masih mengandalkan pertanian sebagai salah satu mata pencaharian mereka, dengan luas lahan pertanian sekitar 1.120ha (BPS, 2014) dengan memiliki berbagai komoditi, salah satunya adalah kacang panjang untuk menambah pendapatan keluarga mereka karena, ternyata dari usahatani kacang panjang mampu memberikan dampak positif di Desa Warembungan, itu sebabnya peneliti tertarik untuk meneliti berapa besar kontribusi dari kacang panjang terhadap pendapatan keluarga petani.

\section{Definisi Kacang Panjang}

Uraian tentang kacang panjang akan dibagi dalam dua bagian yaitu tentang: klasifikasi, kandungan dan hasil panen. Penjelasan rinci sebagai berikut: a. Tanaman kacang panjang merupakan tanaman semak, menjalar, semusim dengan tinggi kurang lebih $2,5 \mathrm{~m}$. Batang tanaman ini tegak, silindris, lunak, berwarna hijau dengan permukaan licin. Daunnya majemuk, lonjong, berseling, panjang 6-8 cm, lebar 3-4,5 cm, tepi rata, pangkal membulat, ujung lancip, pertulangan menyirip, tangkai silindris, panjang kurang lebih $4 \mathrm{~cm}$, dan berwarna hijau. Bunga tanaman ini terdapat pada ketiak daun, majemuk, tangkai silindris, panjang kurang lebih $12 \mathrm{~cm}$, berwarna hijau keputih-putihan, mahkota berbentuk kupu-kupu, berwarna putih keunguan, benang sari bertangkai, panjang kurang lebih $2 \mathrm{~cm}$, berwarna putih, kepala sari kuning, putik bertangkai, berwarna kuning, panjang kurang lebih $1 \mathrm{~cm}$, dan berwarna ungu. Buah tanaman ini berbentuk polong, berwarna hijau, dan panjang 15-25 cm. Bijinya lonjong, pipih, berwarna coklat muda. Akarnya tunggang berwarna coklat muda.

Klasifikasi kacang panjang :

$\begin{array}{ll}\text { Kerajaan } & : \text { Plantae } \\ \text { Divisi } & : \text { Magnoliophyta } \\ \text { Kelas } & : \text { Magnoliophyta } \\ \text { Ordo } & : \text { Fabales }\end{array}$




$\begin{array}{ll}\text { Famili } & \text { :Fabaceae } \\ \text { Upafamili } & \text { : Faboideae } \\ \text { Genus } & \text { :Vigna } \\ \text { Spesies } & \text { :V. unguiculata } \\ \text { Upaspesies } & : \text { V. U sesquipedalis } \\ \text { Nama trinomial: Vigna unguiculata } \\ \text { sesquipedalis (L.) Verdc. }\end{array}$

b. Kandungan Kacang Panjang

Kacang panjang mengandung enam antosianin (sianidin 3-O-galaktosida, sianidin 3-Oglukosida, delfinidin 3-O-glukosida, malvidin 3-Oglukosida, peonidin3-O-glukosida, dan petunidin 3-Oglukosida), flavonol atau glikosida flavonol (kaempferol 3-O-glukosida, quersetin, quersetin 3-Oglukosida, kuersetin 3-O-6-asetilglukosida) (Wong and Chang, 2004), aglikon flavonoid (kuersetin, kaempferol, isorhamnetin) (Lattanzio, 2000). Daun dan akarnya mengandung saponin dan polifenol (Hutapea, 1994). Selain itu juga mengandung protein, karbohidrat, lemak, serat, kalsium, besi, fosfor, potasium, sodium, vitamin B1, vitamin B2, vitamin C, dan niasin (Handri and Rafira, 2003).

c. Hasil panen budidaya kacang panjang

Budidaya kacang panjang sudah siap dipanen setelah 45-50 hari. Buah yang siap dipanen berwarna hijau keputihan. Cara panen dilakukan dengan cara dipetik, biasanya periode panen kacang panjang dalam satu kali siklus budidaya sebanyak 15-18 kali. Hasil produksi kacang panjang bergantung pada banyak variabel, diantaranya jenis varieatas tanaman, mutu benih dan pemeliharaan. (Hutapea, 1994).

\section{Definisi Usahatani}

Menurut Soekartawi (1995) dalam Hatidja (2008) usahatani adalah ilmu yang mempelajari bagaimana seseorang mengalokasikan sumberdaya yang ada secara efektif dan efisien dengan tujuan memperoleh keuntungan yang tinggi pada waktu tertentu. Dikatakan efektif apabila petani atau produsen dapat mengalokasikan sumberdaya yang mereka miliki atau yang dikuasai sebaik-baiknya dan efisien bila pemanfaatan sumberdaya tersebut menghasilkan keluaran (output) yang melebihi masukan (input).

Ilmu usahatani merupakan ilmu yang mempelajari cara-cara petani mengoperasikan dan mengkombinasikan berbagai faktor produksi seperti lahan, tenaga, dan modal sebagai dasar bagaimana petani memilih jenis dan besarnya cabang usahatani berupa tanaman sehingga memberikan hasil yang maksimal (Daniel dalam Suratiyah 2015).
Hernanto (1993) mendefinisikan usahatani sebagai organisasi dalam alam, kerja, dan modal serta pengelolaannya yang ditunjukan dari produksi lapangan pertanian dianggap sebagai perpaduan dari faktor produksi yaitu tanah, tenaga kerja, modal, dan pengelolaan.

Usahatani terdiri dua unsur pokok (Hadisapoetra dalam Parannu, 2007) yaitu :

1. Petani

Orang yang bertindak sebagai sumber manager yang berkewajiban untuk mengambil keputusan, yang menguasai dan mengatur penggunaan dan sumber-sumber produksi yang ada di dalam usahataninya secara efektif sehingga dapat menghasilkan biaya dan pendapatan seperti yang telah direncanakan.

2. Faktor Produksi

Faktor-faktor meliputi :

a. tanah dengan faktor lainnya seperti air, udara, suhu, sinar matahari dan sebagainya yang secara bersama-sama menentukan jenis tanaman yang dapat di usahakan, tingkat peodukasinya dan teknik bercocok tanam yang dapat di pergunakan.

b. Tenaga kerja yang digunakan untuk menjalankan berbagai jenis teknik operasional yaitu tenaga kerja dari dalam keluarga dan tenaga kerja dari luar keluarga.

c. Modal dalam usahatani merupakan benda ekonomi yang dipergunakan untuk memperoleh pendapatan. Di dalamnya termasuk modal tetap yaitu modal yang dipergunakan didalam beberapa kali proses produksi dan modal yang tidak tetap yaitu modal yang habis didalam satu kali produksi.

\section{Tujuan Usahatani}

Tujuan usahatani yaitu bagaimana petani dapat memperbesar hasil sehingga kehidupan seluruh keluarganya menjadi lebih baik (Isaskar, 2014). Tujuan suatu usaha tani yang dilaksanakan oleh rumah tangga petani mempunyai pengaruh yang sangat besar terhadap pengambilan keputusan dan tindakan yang akan diambil, maupun terhadap pandangan rumah tangga akan keberlangsungan dan kemampuannya dalam menerima berbagai pembaharuan, termasuk teknologi pertanian. Usahatani yang dilakukan oleh rumah tangga petani umumnya mempunyai dua tujuan, yaitu mendapatkan keuntungan yang maksimal atau untuk sekuriti (keamanan) dengan cara meminimalkan risiko, termasuk keinginan untuk memiliki persediaan pangan yang cukup untuk konsumsi ru- 
mah tangga dan selebihnya untuk dijual (Soedjana, 2007). Untuk mencapai tujuan tersebut, petani selalu memperhitungkan untung ruginya walau tidak secara tertulis. Dalam ilmu ekonomi dikatakan bahwa petani membandingkan antara hasil yang diharapkan akan diterima pada waktu panen (Isaskar, 2014).

\section{Konsep Biaya}

Biaya usahatani dapat dibedakan menjadi dua
1. Biaya tetap (fixed cost), yaitu biaya sewa lahan, pajak lahan, biaya bunga, penyusutan, per usahatani dengan satuan Rupiah (Rp).

2. Biaya tidak tetap (variable cost), yaitu biaya yang digunakan untuk membeli atau menyediakan bahan baku yang habis dalam satu kali produksi.

(Suratiyah, 2015):

$$
\begin{aligned}
& \mathrm{TC}=\mathrm{FC}+\mathrm{VC} \\
& \text { dimana }: \\
& \mathrm{TC}=\text { total cost } \text { (biaya) } \\
& \mathrm{FC}=\text { fixed cost } \text { (biaya tetap) } \\
& \mathrm{VC}=\text { variable cost } \text { (biaya tidak tetap) }
\end{aligned}
$$

\section{Konsep Penerimaan}

Menurut Hermanto (1993), penerimaan usahatani yaitu dari sumber usahatani meilputi nilai penjualan hasil, penambahan jumlah inventaris, nilai produk yang dikonsumsi petani dan keluarga. Pe- nerimaan adalah hasil perkalian antara produksi yang diperoleh dengan harga jualnya. Secara sistematis dapat ditulis dalam bentuk persamaan sebagai berikut:

$$
\begin{aligned}
& \text { TR = } \mathrm{Yi} \text { X Pyi } \\
& \text { Dimana : } \\
& \text { TR = total revenue } \text { (penerimaan) } \\
& \mathrm{Yi}=\text { output } \\
& \text { (jumlah produksi kacang panjang) } \\
& \text { Pyi = price } \\
& \text { (harga kacang panjang) }
\end{aligned}
$$

\section{Konsep Pendapatan Usahatani}

Pendapatan usahatani adalah selisih antara penerimaan dan semua biaya dalam meningkatkan pendapatan, maka petani harus berusaha untuk meningkatkan hasil produksi agar memperoleh peningkatan pendapatan dengan memaksimalkan faktor produksi terutama tenaga kerja yang merupakan salah satu faktor produksi yang sangat mempengaruhi dalam usahatani keluarga (Soekartawi, 1995).

Pendapatan meliputi tenaga kerja sendiri, upah petani, bunga modal sendiri, dan keuntungan. Atau pendapatan kotor dikurangi biaya alat-alat luar dan bunga modal luar (Suratiyah, 2015).

\section{Konsep Pendapatan Usahatani Keluarga}

Keluarga yang terdiri dari bapak, ibu, dan anak-anak, memiliki peranannya masing-masing, dimana setiap peran haruslah dilaksanakan dengan penuh tanggung jawab demi keluarganya. Bagi keluarga petani, bekerja merupakan kegiatan untuk memperoleh pendapatan guna memenuhi kebutuhan hidup keluarga. Pendapatan keluarga petani adalah pendapatan yang diperoleh dari hasil kerja setiap anggota keluarga yang sudah bekerja.

Menurut Tohir (1993), keberhasilan atau kesuksesan usahatani dapat dilihat dari besarnya pendapatan keluarga petani. Pendapatan keluarga petani yang diperoleh disamping untuk mencukupi kebutuhan hidupnya juga memungkinkan bagi petani untuk melanjutkan kegiatannya. Dengan demikian pendapatan yang diterima akan dialokasikan pada berbagai kebutuhan. 


\section{Kontribusi}

Menurut Kamus Ekonomi (Guritno, 1992) kontribusi adalah sesuatu yang diberikan bersamasama dengan pihak lain untuk tujuan biaya, atau kerugian tertentu atau bersama. Sedangkan, menurut Kamus Besar Bahasa Indonesia, pengertian Kontribusi artinya sumbangan atau bagian.
Kontribusi pendapatan usahatani kacang panjang terhadap pendapatan keluarga petani adalah besarnya sumbangan atau bagian pendapatan dari usahatani kacang panjang terhadap keseluruhan pendapatan keluarga. Untuk mengetahui besarnya kontribusi usahatani kacang panjang dapat dihitung berdasarkan presentase yaitu dengan pendekatan :

$$
\text { Kontribusi }=\frac{\text { Pendapatan Usahatani Kacang Panjang }}{\text { Total Pendapatan Keluarga }} \text { X } 100 \%
$$

\section{Perumusan Masalah}

Berdasarkan latar belakang di atas, maka yang menjadi masalah dalam penelitian ini adalah: Berapa besar kontribusi usahatani kacang panjang terhadap pendapatan keluarga petani di Desa Warembungan Kecamatan Pineleng?

\section{Tujuan dan Manfaat penelitian}

Tujuan dari penelitian ini adalah :

Mengetahui berapa besar kontribusi usahatani kacang panjang terhadap pendapatan keluarga petani di Desa Warembungan Kecamatan Pineleng.

Dengan tercapainya tujuan penelitian ini, maka diharapkan penelitian ini dapat memberikan manfaat yang baik sebagai bahan informasi tentang kontribusi usahatani kacang panjang terhadap pendapatan rumah tangga petani di Desa Warembungan Kecamatan Pineleng.

\section{METODE PENELITIAN}

\section{Waktu dan Tempat Penelitian}

Penelitian ini akan dilaksanakan selama 3 bulan terhitung bulan Mei sampai Juli 2015, sejak persiapan hingga penyusunan laporan hasil penelitian. Penelitian dilaksanakan di Desa Warembungan Kecamatan Pineleng.

\section{Metode Pengumpulan Data}

Metode pengumpulan data dilakukan dengan metode sensus. Data yang digunakan yaitu data primer diperoleh melalui wawancara langsung dengan petani responden berdasarkan pertanyaan yang telah disusun dalam kuisioner dan data sekunder diperoleh dari instansi yang terkait dengan penelitian ini.

\section{Metode Pengambilan Sampel}

Penentuan lokasi pengambilan sampel dilakukan secara sengaja (purposive sampling), yaitu di Desa Warembungan Kecamatan Pineleng. Penelitian ini diambil berdasarkan jumlah petani yang mengusahakan usahatani kacang panjang, dengan jumlah petani 20 orang.

\section{Konsep Pengukuran Variabel Penelitian}

Batasan variabel yang akan diteliti adalah sebagai berikut :

1. Luas Lahan, yaitu jumlah luas keseluruhan lahan yang digunakan untuk usahatani kacang panjang (ha)

2. Jumlah produksi, hasil yang diperoleh petani dalam satu kali panen $(\mathrm{kg})$

3. Harga jual yang berlaku ditingkat petani $(\mathrm{Rp} / \mathrm{kg})$

4. Biaya Usahatani kacang panjang, yaitu biaya yang dikeluarkan selama proses produksi :

a. Biaya tetap (fixed cost)

b. Biaya tidak tetap (variable cost)

- $\quad$ Biaya sarana produksi (Rp)

- $\quad$ Bibit $(\mathrm{Rp} / \mathrm{kg})$

- $\quad$ Pupuk $(\mathrm{Rp} / \mathrm{kg})$

- $\quad$ Pestisida $(\mathrm{Rp} / \mathrm{kg})$

- $\quad$ Biaya tenaga kerja (Rp)

5. Pendapatan usahatani kacang panjang yaitu, selisih antara penerimaan dengan biaya $(\mathrm{Rp})$

6. Pengeluaran usahatani lain yaitu, seluruh biaya yang dikeluarkan selama proses produksi $(\mathrm{Rp})$

7. Pendapatan usahatani lain yaitu, pendapatan usahatani diluar usahatani kacang panjang, diperoleh dari selisih antara penerimaan dengan pengeluaran $(\mathrm{Rp})$ 
8. Pendapatan diluar pertanian yaitu, jumlah pendapatan dari berbagai sumber (Rp)

9. Total pendapatan yaitu, jumlah keseluruhan pendapatan yang diperoleh dari pendapatan usahatani kacang panjang, pendapatan usahatani selain kacang panjang dan pendapatan diluar pertanian (Rp)

\section{Metode Analisis Data}

Data yang diperoleh dalam penelitian ini di analisis secara deskriptif

$$
\begin{array}{lll}
\mathrm{I}= & \mathrm{TR} & -\mathrm{TC} \\
\text { Dimana : } & & \mathrm{I}=\text { income }(\text { pendapatan }) \\
& \\
& \mathrm{TR}=\text { total revenue }(\text { penerimaan }) \\
& \mathrm{TC}=\text { total cost } \text { (biaya) }
\end{array}
$$
rumus :

Selanjutnya, untuk mengetahui besarnya kontribusi pendapatan kacang panjang maka digunakan
10. Kontribusi pendapatan, sumbangan atau bagian pendapatan usahatani kacang panjang terhadap pendapatan keluarga

11. $(\%)$

- Umur petani (tahun)

- Tingkat pendidikan (SD, SMP, SMA, Perguruan Tinggi)

- Jumlah anggota keluarga (orang)

dan akan disajikan dalam bentuk tabel. Untuk menghitung pendapatan digunakan rumus analisis pendapatan usahatani :

$$
\text { Kontribusi }=\frac{\text { Pendapatan Usahatani Kacang Panjang }}{\text { Total Pendapatan Keluarga }} \text { X } 100 \%
$$

\section{HASIL DAN PEMBAHASAN}

Desa Warembungan merupakan salah satu desa dari 14 desa yang berada di Kecamatan Pineleng. Pada Tabel 1 menunjukkan jumlah penduduk menurut jenis pekerjaan di Kecamatan Pineleng. Desa Warembungan berada pada urutan nomor 9 .

\section{Letak dan Luas Wilayah}

Desa Warembungan terletak di Kabupaten Minahasa di wilayah Kecamatan Pineleng. Secara umum, Desa Warembungan memiliki luas lahan 1100ha dengan memiliki 15 dusun. Adapun batasbatas wilayah di Desa Warembungan adalah sebagai berikut :

- Sebelah utara berbatasan dengan Desa Pineleng Indah 2

- Sebelah selatan berbatasan dengan Desa Tinoor

- Sebelah barat berbatasan dengan Desa Sea

- Sebelah timur berbatasan dengan Desa Pineleng

\section{Keadaan Penduduk}

Desa Warembungan memiliki jumlah penduduk yaitu 4987 jiwa dengan jumlah keluarga 1204 kk. Komposisi penduduk Desa Warembungan dapat dilihat pada tabel 2 berikut ini :

\section{Tabel 2. Jumlah penduduk Desa Warembungan} Berdasarkan Jenis Kelamin.

\begin{tabular}{lrc}
\hline $\begin{array}{l}\text { Jenis Ke- } \\
\text { lamin }\end{array}$ & $\begin{array}{c}\text { Jumlah Re- } \\
\text { sponden }\end{array}$ & $\begin{array}{c}\text { Per- } \\
\text { sentase } \\
(\%)\end{array}$ \\
\hline Laki-laki & 2344 & 47.38 \\
Perempuan & 2643 & 53.42 \\
\hline Jumlah & 4947 & 100.00 \\
\hline Sumber : Diolah dari Data Primer, 2015 \\
Perekonomian \\
Penduduk Desa Warembungan memiliki mata \\
pencaharian sebagai : Petani, Penggarap, PNS, Guru, \\
TNI/Polri, Pensiunan, Swasta. Jenis mata pencaharian \\
penduduk secara rinci dapat dilihat pada Tabel 3. \\
Tabel 3 menunjukkan jenis mata pencaharian \\
penduduk Desa Warembungan serta persentase mas-
\end{tabular}


ing-masing jenis mata pencaharian. Dari Tabel dapat dilihat bahwa jumlah dari jenis mata pencaharian sebagai Petani Penggarap yang paling tinggi, dengan jumlah 318 orang dengan persentase $42.05 \%$ dan mata pencaharian sebagai Guru dengan jumlah 8 orang dengan persentase $0.80 \%$ adalah yang terendah.

Tabel 3. Jenis Mata Pencaharian Penduduk Desa Warembungan Tahun 2015

\begin{tabular}{lcl}
\hline Jenis Mata Pencaharian & Jumlah(Orang) & $(\%)$ \\
\hline Petani & & \\
Petani Penggarap & 124 & 12.50 \\
PNS & 318 & 42.05 \\
Guru & 150 & 15.12 \\
TNI/Polri & 8 & 0.80 \\
Pensiunan & 30 & 3.02 \\
Swasta/dll & 31 & 3.12 \\
& 331 & 33.36 \\
\multicolumn{2}{c}{ Jumlah } & \\
\hline \multicolumn{2}{l}{ Sumber }
\end{tabular}

Sumber : Diolah dari Data Primer, 2015

Karakteristik Petani Responden

Dalam pengambilan sampel petani responden di Desa Warembungan, di ambil secara sengaja (purposive sampling) dengan jumlah 20 responden. Adapun yang dimaksud dengan karakteristik petani terdiri dari umur, tingkat pendidikan, jumlah tanggungan keluarga, jenis usaha lain diluar usahatani kacang panjang dan luas lahan.

\section{Umur Petani}

Umur seseorang menentukan prestasi kerja atau kinerja orang tersebut. Semakin tua umur tenaga kerja maka secara kerja maka secara fisik akan terasa berat pekerjaannya, sehingga akan semakin turun pula prestasinya. Namun, dalam hal ini tanggung jawab semakin tua umur tenaga kerja tidak akan berpengaruh karena justru semakin berpengalaman ( $\mathrm{Su}-$ ratiyah, 2015). Tingkat umur dari responden dapat dilihat dalam Tabel 4.

Tabel 4 menunjukkan jumlah dan persentase petani kacang panjang berdasarkan umur petani yang menjadi responden penelitian. Berdasarkan presentase menunjukkan ada 3 kelompok umur petani yang sama yaitu 41-50, 51-60, 61-70 tahun.
Tabel 4. Jumlah Responden menurut Golongan Umur di Desa Warembungan

\begin{tabular}{lcc}
\hline Umur & $\begin{array}{c}\text { Jumlah } \\
\text { Tanggungan } \\
\text { (Orang) }\end{array}$ & $\begin{array}{l}\text { Persentase } \\
(\%)\end{array}$ \\
\hline $30-40$ & 2 & 10.00 \\
$41-50$ & 6 & 30.00 \\
$51-60$ & 6 & 30.00 \\
$61-70$ & 6 & 30.00 \\
\hline Jumlah & 20 & 100.00 \\
\hline Sumber : Diolah dari Data Primer, 2015 \\
\multicolumn{3}{c}{ Tingkat Pendidikan }
\end{tabular}

Pendidikan merupakan salah satu hal yang sangat penting bagi manusia yang merupakan bekal dalam hidupnya. Karena dengan pendidikan yang cukup seseorang akan memiliki pola pikir yang lebih maju dan berkembang. Tingkat pendidikan petani responden dapat dilihat pada Tabel 4 .

Tabel 5. Jumlah Petani Kacang Panjang Berdasarkan Tingkat Pendidikan

\begin{tabular}{lcl}
\hline $\begin{array}{l}\text { Tingkat } \\
\text { Pendidikan }\end{array}$ & $\begin{array}{l}\text { Jumlah } \\
\text { (Responden) }\end{array}$ & $(\%)$ \\
SD & 10 & 50.00 \\
SMP & 5 & 25.00 \\
SMA/S & 4 & 20.00 \\
MK & 1 & 5.00 \\
S1 & & \\
\hline Jumlah & 20 & 100.00
\end{tabular}

Sumber : Diolah dari Data Primer, 2015

Pada Tabel 5 menunjukkan jumlah dan persentase petsni kacang panjang berdasarkan tingkat pendidikan. Dari tabel dapat dilihat jumlah petani dengan tingkat pendidikan SD berjumlah 10 orang merupakan jumlah terbanyak dan tingkat pendidikan S1 hanya berjumlah 1 orang.

\section{Jumlah Tanggungan Keluarga}

Jumlah tanggungan keluarga bisa membantu dalam penyediaan tenaga kerja. Untuk lebih jelasnya jumlah tanggungan keluarga petani dapat dilihat pada Tabel 6. 
Tabel 6 menunjukkan jumlah tanggungan keluarga petani terbanyak adalah pada 1-2 orang dengan jumlah 12 orang dengan persentase adalah $0.60 \%$.

Tabel 6. Jumlah dan Persentase Petani Responden Menurut Jumlah Tanggungan Keluarga

\begin{tabular}{|c|c|c|}
\hline $\begin{array}{l}\text { Jumlah } \\
\text { Anggota } \\
\text { Keluarga } \\
\text { (Orang) }\end{array}$ & $\begin{array}{c}\text { Jumlah } \\
\text { (Responden) }\end{array}$ & $(\%)$ \\
\hline $1-2$ & 12 & 60.00 \\
\hline $3-4$ & 6 & 30.00 \\
\hline $5-6$ & 2 & 10.00 \\
\hline Jumlah & 20 & 100.00 \\
\hline
\end{tabular}

Sumber : Diolah dari Data Primer, 2015

\section{Luas Lahan}

Status Kepemilikan lahan dari petani responden adalah milik sendiri dengan luas lahan dari 0,5 - 2 ha. Tabel 7 menunjukkan luas lahan usahatani kacang panjang yang dimiliki oleh responden.

Tabel 7 menunjukkan jumlah dan persentase dari petani responden menurut luas lahan dari petani dalam penelitian ini. Hampir semua petani memiliki kisaran luas lahan $0,5-1$ ha dengan jumlah 17 responden dengan persentase $85,00 \%$.

Tabel. 7. Jumlah Petani Responden Menurut Luas Lahan

\begin{tabular}{lrl}
\hline $\begin{array}{l}\text { Luas Lahan } \\
(\mathrm{Ha})\end{array}$ & $\begin{array}{l}\text { Jumlah } \\
\text { (Responden) }\end{array}$ & $\begin{array}{l}\text { Persentase } \\
(\%)\end{array}$ \\
\hline $0,5-1$ & 17 & 85.00 \\
$\geq 1$ & 3 & 15.00 \\
\hline Jumlah & 20 & 100.00 \\
\hline
\end{tabular}

Sumber : Diolah dari Data Primer, 2015

\section{Jumlah Produksi Kacang Panjang}

Produksi merupakan salah satu tujuan bagi petani untuk mendapatkan pendapatan yang tinggi. Produksi merupakan hasil yang diperoleh pada saat panen.
Tabel 8 menunjukkan jumlah dan persentase dari produksi usahatani kacang panjang dalam masa panen selama 1 tahun. Dengan jumlah panen terbanyak berkisar antara 21.000 sampai 30.000 (ikat) kacang panjang dengan jumlah 10 responden atau $50.00 \%$. Jumlah Produksi kacang panjang di Desa Warembungan tidak bergantung pada luas lahan, karena kebanyakan petani hanya memproduksi kacang panjang sebanyak 21.00030.000 (ikat) selama 2 kali masa tanam dalam jangka waktu 1 tahun. Petani yang menghasilkan jumlah 10.000-20.000 (ikat) rata-rata terserang hama dan penyakit, hal ini disebabkan karena, petani tidak memakai pestisida untuk mengendalikan hama dan penyakit pada tanaman kacang panjang, sedangkan petani yang memiliki produksi sebanyak 31.000-50.000 ikat dalam 2 kali panen memakai pestisida untuk melindungi tanaman kacang panjang petani dari serangan hama dan penyakit.

Tabel 8. Menunjukkan Hasil dari Produksi Kacang Panjang Selama 1 Tahun.

\begin{tabular}{ccc}
\hline $\begin{array}{c}\text { Jumlah Produksi } \\
\text { (ikat) }\end{array}$ & $\begin{array}{c}\text { Jumlah } \\
\text { (Responden) }\end{array}$ & $(\%)$ \\
\hline $10.000-20.000$ & 8 & 40.00 \\
$21.000-30.000$ & 10 & 50.00 \\
$31.000-50.000$ & 2 & 10.00 \\
\hline Jumlah & 20 & 100.00 \\
\hline
\end{tabular}

Sumber : Diolah dari Data Primer, 2015

\section{Harga Kacang Panjang}

Harga Kacang Panjang yang berlaku ditingkat petani yaitu Rp. 1000 per ikatnya.

\section{Total Biaya Usahatani Kacang Panjang}

Pengeluaran atau biaya produksi adalah keseluruhan biaya yang digunakan dalam suatu proses produksi yang berlangsung dalam masa produksi. Biaya produksi terdiri dari biaya tetap dan biaya variabel. Biaya tetap yaitu pajak lahan, penyusutan dan biaya variabel yaitu biaya tenaga kerja, dapat dilihat pada Tabel 9.

Pada Tabel 9 menunjukkan jumlah rata-rata biaya yang dikeluarkan dalam memproduksi kacang panjang selama 1 tahun. 
Tabel 9. Menunjukkan Jumlah dan Persentase Biaya produksi Usahatani Kacang Panjang Selama 1 Tahun.

\begin{tabular}{lcc}
\hline Komponen Biaya & $\begin{array}{c}\text { Rata-Rata } \\
(\mathrm{Rp})\end{array}$ & $\begin{array}{c}\text { Persentase } \\
(\%)\end{array}$ \\
\hline Biaya tetap & & \\
- Pajak & - & - \\
- $\quad$ Penyusutan & 36.825 & 0.75 \\
& & \\
Biaya Variabel & 4.100 .000 & 83.59 \\
- Tenaga kerja & 370.000 & 7.59 \\
- Benih & 130.000 & 2.64 \\
- Pupuk & 120.000 & 2.44 \\
- Pestisida & 128.960 & 2.62 \\
- Tiang Bambu & 22.080 & 0.45 \\
- Karet & & \\
\hline$\quad \quad$ Jumlah & 4.907 .865 & 100.00 \\
\hline
\end{tabular}

Sumber : Diolah dari Data Primer, 2015

Pendapatan Usahatani Kacang Panjang

Tinggi rendahnya pendapatan petani tergantung pada produksi, harga jual dan biaya produksi yang dikeluarkan selama proses produksi.

Tabel 10 menunjukkan bahwa rata-rata penerimaan yang di peroleh yaitu Rp. 22.170.000 dikurangi biaya selama produksi Rp 4.989.670, jadi total rata-rata yang menjadi pendapatan petani yaitu Rp 17.168.830 setiap tahunnya.

Tabel 10. Rata-rata Penerimaan, Pendapatan Petani Responden pada Usahatani Kacang Panjang selama 1 Tahun.

\begin{tabular}{cc}
\hline $\begin{array}{c}\text { Komponen } \\
\text { Biaya }\end{array}$ & Rata-rata (Rp) \\
\hline Penerimaan & Rp. 22.170 .000 \\
Pengeluaran & Rp. 4.989 .670 \\
Pendapatan & Rp. 17.168 .830
\end{tabular}

Sumber : Diolah dari Data Primer, 2015

\section{Biaya Produksi}

Pada usahatani selain kacang panjang yaitu adalah usahatani sayur Gedi yang ditanam oleh petani responden. Seperti yang ditunjukan pada Tabel 11.
Tabel 11. Rata-rata Biaya Produksi Usahatani Lain selama 1 Tahun

\begin{tabular}{clcl}
\hline $\begin{array}{c}\text { Jenis Tana- } \\
\text { man }\end{array}$ & $\begin{array}{l}\text { Jumlah } \\
\text { Produksi }\end{array}$ & $\begin{array}{l}\text { Harga } \\
(\mathrm{Rp})\end{array}$ & $\begin{array}{l}\text { Pendapatan } \\
(\mathrm{Rp})\end{array}$ \\
\hline Sayur Gedi & 3136 ikat & 1000 & 3.136 .842
\end{tabular}

Jagung

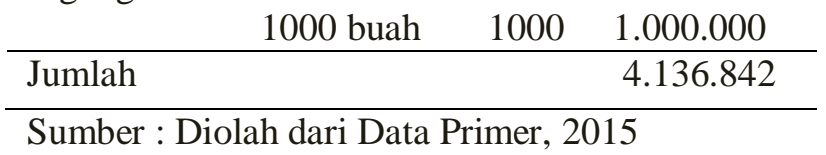

Pendapatan diluar Usaha Pertanian

Pekerjaan merupakan hal yang penting dalam memenuhi kebutuhan hidup sehari-hari. Selain usahatani kacang panjang dan usahatani lainnya, petani di Desa Warembungan juga memiliki mata pencaharian yang tetap maupun tidak tetap.

Tabel 12 menunjukkan jumlah pendapatan diluar usahatani. Dari hasil penelitian, pendapatan yang diperoleh diluar usahatani yaitu Guru yang memilik pendapatan selama satu bulan hingga Rp 36.000.000 selama 1 tahun, pedagang, tukang yang memperoleh pendapatan Rp. 43.200.000 selama 1 tahun, serta pekerja swasta yang memiliki pendapatan Rp 43.200.000 selama 1 tahun.

Tabel 12. Rata-rata Pendapatan Keluarga Petani di Luar Usahatani selama 1 Tahun.

\begin{tabular}{ll}
\hline Jenis Pekerjaan & $\begin{array}{l}\text { Pendapatan yang di- } \\
\text { peroleh }\end{array}$ \\
\hline Pedagang & Rp. 43.200.000 \\
Tukang & Rp 43.200.000 \\
Guru & Rp. 36.000.000 \\
Swasta & Rp. 43.200.000 \\
Ojek & Rp. 36.000.000 \\
\hline Total Pendapatan & Rp. 42.092.300 \\
Rata-rata & \\
\hline Sumber : Diolah dari Data Primer
\end{tabular}

Kontribusi Pendapatan Usahatani Kacang Panjang Terhadap Pendapatan Rumah Tangga Petani.

Kontribusi adalah sumbangan atau bagian, kontribusi usahatani kacang panjang terhadap pendapatan keluarga adalah besarnya sumbangan atau pendapatan yang diperoleh dari usahatani kaacang panjanh terhadap keseluruhan pendapatan dari usahataninya. Besarnya kontribusi usahatani kacang panjang dapat dilihat pada Tabel 13. 
Tabel 13. Kontribusi Pendapatan Usahatani Kacang Panjang Terhadap Pendapatan Keluarga Petani Selama 1 Tahun

\begin{tabular}{llc}
\hline \multicolumn{1}{c}{ Jenis Pekerjaan } & Pendapatan Rp. & Rata-rata \\
\hline $\begin{array}{l}\text { Usahatani kacang } \\
\text { panjang }\end{array}$ & 343.376 .600 & 17.168 .830 \\
$\begin{array}{l}\text { Usahatani lain } \\
\text { diluar kacang pan- }\end{array}$ & 54.101 .000 & 2.705 .050 \\
jang & \\
$\begin{array}{l}\text { Usaha lain diluar } \\
\text { pertanian }\end{array}$ & 547.200 .000 & 42.092 .300 \\
\hline $\begin{array}{l}\text { Kontribusi } \\
\text { Pendapatan Usahatani Kacang Panjang }\end{array}$
\end{tabular}

Kontribusi $=\frac{\text { Rp. } 343.376 .600}{\text { Rp. } 944.677 .600} \times 100 \%=36.33 \%$

Jadi, Total Kontribusi yang didapat dari usahatani kacang panjang yaitu $36.33 \%$ setiap tahunnya.

\section{KESIMPULAN}

Kesimpulan dari penelitian ini yaitu usahatani kacang panjang dapat memberikan kontribusi yang cukup bagi pendapatan keluarga petani di Desa Warembungan dengan hasil persentase $36.33 \%$ disetiap tahunnya. Ini berarti usahatani kacang panjang dapat menjadi sumber pendapatan petani karena, nilai pendapatan usahatani kacang panjang terhadap total pendapatan keluarga petani dapat memberikan pengaruh yang cukup baik.

\section{DAFTAR PUSTAKA}

BPS Kabupaten Minahasa. Data Statistik kecamatan Pineleng tahun 2014 . Sulawesi Utara.

Hatidja, M. 2008. Analisis Pendapatan Usahatani Salak (Studi Kasus Desa Pangu Kecamatan Ratahan). Skripsi. Fakultas Pertanian. Manado

Handri and Rafira, 2003. Mempercantik Diri dengan Buah dan Sayur. Penerbit Pikiran Rakyat Cyber Media. Jakarta
Hernanto, F, 1993. Ilmu Usahatani. Departemen Sosial Ekonomi, IPB. Bogor.

Hutapea, J,R,1994. Inventaris Tanaman Obat Indonesia(III). Badan Penelitian dan Pengembang Kesehatan, Departemen Kesehatan. Jakarta.

Isaskar, Riyanti. 2014. Modul 1. Pendahuluan: Pengantar Usaha Tani Laboratorium Analisis dan Manajemen Agribisnis. Fakultas Pertanian Universitas Brawijaya.

Lattanzio, V., Arpaia, S., Cardinali, A., Di Venere, D., and Linsalata, V., 2000, Role Of Endogenous Flavonoids In Resistance Mechanism of Vigna To Aphids, J. Agric. Food Chem.

Parannu, M. 2007. Kontribusi Usahatani Bunga Potong Terhadap Pendapatan Petani Kecamatan Tomohon. Skripsi. Jurusan Sosial Ekonomi Fakultas Pertanian. Unsrat. Manado

Salawati, U., Anita, A. S. 2011. Analisis Pendapatan Penerimaan Bantuan Langsung MasyarakatPengembangan Uahatani Agribisnis Perdesaan (BLM-PUAP) DI Kabupaten Barito Kuala. Jurusan Agribisnis FMIPA-Univ. Terbuka jl. Cabe Raya.

Ken Suratiyah. 2015. Ilmu Usahatani. Penerbit Swadaya. Jakarta

Soedjana, Tjeppy D. 2007. Sistem Usaha Tani Terintegrasi Tanaman-Ternak Sebagai Respons Petani Terhadap Faktor Resiko Jurnal Litbang Pertanian. Badan Penelitian dan Pengembangan Pertanian. Jakarta.

Soekartawi, A, 1995. Analisis Usahatani. Universitas Indonesia. Jakarta

Timbulus C. 2015. Kontribusi Usahatani Salak Terhadap Pendapatan Keluarga Petani di Wilayah Pangu Kecamatan Ratahan. Skripsi. Jurusan Sosial Ekonomi Fakultas Pertanian. Unsrat. Manado

Tohir, A. 1993. Seuntai Pengetahuan Usahatani Indonesia. Rineke Cipta. Jakarta

Wong, Y.S., and Chang, Q., 2004, Identification Of Flavonoids In Hakmeitau Beans (Vigna Sinensis) By High-Performance Liquid Chromatography-Electrospray Mass Spectrometry (LC-ESI/MS), J. Agric. Food Chem 